\title{
Mini-Ulasan Adsorpsi Anthrasena, Fenanthrena dan Fluorena Menggunakan Material Berbasis Karbon Berpori, Silika dan Zeolit
}

\author{
Winda Br Purba ${ }^{1}$, Grandprix Thomryes Marth Kadja², Muhammad Yudhistira Azis ${ }^{1 *}$ \\ ${ }^{1}$ Kelompok Keahlian Kimia Analitik, Fakultas Matematika dan IImu Pengetahuan Alam, Institut \\ Teknologi Bandung, Jl. Ganesha No 10, Bandung 40132, Indonesia \\ ${ }^{2}$ Kelompok Keahlian Kimia Anorganik dan Fisik, Fakultas Matematika dan IImu Pengetahuan Alam, \\ Institut Teknologi Bandung, Jl. Ganesha No 10, Bandung 40132, Indonesia \\ *Corresponding author: m.yudhistira.azis@mail.chem.itb.ac.id
}

\begin{abstract}
Polycyclic Aromatic Hydrocarbons (PAH) are classified as organic pollutants with serious carcinogenicity, mutagenicity, and teratogenicity in living organisms. Also, they are considerably stable in the aquatic environment, thus, increasingly threatening human life. Anthracene, Phenanthrene and Fluorene are typical $P A H s$, mostly found in the industrial waste. The removal of PAH compounds is performed through adsorption as the most effective method for treating polluted water due to its low cost and simplicity in removing pollutants content. Herein, a mini-review focusing on the adsorption of PAH with various porous adsorbents such as, activated carbon, biochar, Grafena, zeolite and mesoporous, is comprehensively presented. Several factors that influence the adsorption capability of the adsorbents, including specific surface area, pore size and adsorbent pore volume, are thoroughly elaborated. The adsorption PAH were obtained in the $\mathrm{pH}$ range of 2-12, contact times of 1-24 hours, and temperatures of 20-45 ${ }^{\circ} \mathrm{C}$, and PAH concentrations of 2-60 mg / L, which provide a reference for the specific range in evaluating the adsorption performance of $P A H$ with the used adsorbent.
\end{abstract}

Keywords: adsorption; adsorbents; PAH.

\begin{abstract}
Abstrak
Senyawa Polisiklik Aromatik Hidrokarbon (PAH) merupakan salah satu senyawa polutan organik yang bersifat karsinogen, mutagen dan teratogen pada organisme, sehingga dapat bertahan dalam air untuk waktu yang lama. Antrasena, Fenantrena, dan Fluorena adalah jenis PAH yang banyak dihasilkan dari limbah industri. Penghilangan senyawa PAH dilakukan dengan metode adsorpsi sebagai metode paling efektif untuk pengolahan air yang tercemar karena biaya yang rendah dan sederhana dalam menghilangkan kandungan polutan. Pada penelitian ini telah dilakukan studi literatur terhadap adsorpsi PAH dengan berbagai adsorben bahan karbon berpori seperti Karbon Aktif, Biochar dan Grafena dan adsorben bahan mesoporus Silika seperti PMO, MCM-41, NH2-SBA-15, dan klinoptilolit (zeolite). Terdapat beberapa faktor yang mempengaruhi kemampuan adsorpsi dari Karbon aktif dan silika seperti luas permukaan spesifik, ukuran
\end{abstract}

DOI: http://dx.doi.org/10.12962/j25493736.v6i2.9725 
pori dan volume pori adsorben. Parameter adsorpsi PAH dengan karbon aktif dan silika yang diperoleh seperti pH dalam rentang 2-12, waktu kontak 1-24 jam, suhu $20-45^{\circ} \mathrm{C}$, konsentrasi PAH 2-60 mg/L memberikan acuan rentang spesifik dalam mengevaluasi kinerja adsorpsi PAH dengan adsorben yang digunakan.

Kata kunci: adsorpsi; adsorben; PAH.

\section{Pendahuluan}

Pencemaran air merupakan salah satu masalah lingkungan. Pencemaran air terjadi akibat adanya logam-logam berat dan senyawa organik yang melebihi kadar yang sudah ditetapkan. Senyawa PAH merupakan salah satu senyawa organik yang menjadi sumber pencemaran air. PAH berasal dari berbagai aktivitas baik aktivitas alami maupun aktivitas antropogenik. Aktivitas alami yang menghasilkan senyawa PAH adalah seperti letusan gunung berapi, perembesan minyak, kebakaran hutan. Sedangkan aktivitas antopogenik penghasil senyawa kontaminan ini adalah akibat dari kegiatan industri seperti industri minyak bumi, pembangkit tenaga listrik, batu bara, aspal dan mesin-mesin pembakaran [1]. Menurut WHO (2000) ambang batas kandungan PAH dalam air adalah $0,05 \mu \mathrm{g} / \mathrm{L}$ [2]. Hasil penelitian menunjukkan bahwa PAH adalah polutan yang bersifat karsinogen, mutagen atau teratogen pada organisme, senyawa ini dapat bertahan dalam air untuk waktu yang lama [3]. Senyawa PAH yang mengendap ke dasar perairan sangat beracun bagi organisme perairan. Senyawa PAH dianggap sebagai polutan prioritas karena berbahaya bagi organisme [4] dan berbagai jenis $\mathrm{PAH}$ merupakan polutan yang berpotensi membahayakan kesehatan manusia meskipun pada tingkat konsentrasi yang rendah [5].

PAH terdiri atas dua klasifikasi PAH dengan massa molekul rendah dan massa molekul yang tinggi. Beberapa studi melaporkan bahwa tingkat ketoksikan dari senyawa PAH tertinggi dimiliki oleh $\mathrm{PAH}$ dengan struktur satu, dua dan tiga benzena [2]. Antrasena, fluorena, dan fenantrena merupakan senyawa PAH molekular rendah yang memiliki tiga cincin benzena. Penelitian Mojiri, et al (2019) melaporkan kandungan fenantrena, antrasena dan fluorena berturutturut dalam air tercemar adalah 33,06.495.000 ng/L; 42,0-294,9 ng/L; dan 20$234.000 \mathrm{ng} / \mathrm{L}$ [6]. Senyawa fenantrena adalah senyawa yang paling banyak dihasilkan dari insinerasi biosolid, limbah berbahaya, petrokimia, dan pembakaran batubara. Konsentrasi fenantrena pada air limbah minyak bumi mencapai 7,6-9,9 $\mu \mathrm{g} / \mathrm{L}$ [6] Antrasena adalah senyawa yang banyak dihasilkan dari industri aluminium dan pembakaran batubara. Fluorena merupakan 
senyawa yang juga banyak dihasilkan dari pembakaran batu bara [2].

Berbagai metode telah dilakukan dalam mendegradasi PAH di lingkungan perairan, seperti fotolisis, oksidasi, biodegradasi, adsorpsi, dan volatilisasi [7]. Namun, beberapa dari metode-metode tersebut kurang efektif dilakukan karena PAH stabil dan resisten di lingkungan karena PAH memiliki kelarutan dan volatilitas yang rendah serta respon yang lambat terhadap biodegradasi [5]. Adsorpsi adalah salah satu metode yang dianggap sebagai metode efektif untuk pengolahan air yang tercemar karena biaya yang rendah, sederhana dan ketidakpekaan terhadap polutan yang beracun. Adsorben yang sering digunakan dalam adsorpsi senyawa PAH adalah bahan karbon berpori dan mesoporus silika. Jenis-jenis adsorben bahan karbon berpori, seperti : karbon aktif, Granula Active Carbon (GAC), Powder Active Carbon (PAC), Biochar, dan Grafena. Adsorben mesoporus silika yang paling banyak digunakan adalah SBA-15, MCM-41, dan modifikasinya (PMO/periodic mesoporous organosilica). Bahan kabon berpori memiliki beberapa kekurangan seperti mudah terbakar, tidak tahan terhadap suhu yang tinggi [8]. Berbeda dengan karbon berpori, mesoporus silika memiliki beberapa keunggulan seperti ketahanan terhadap suhu yang tinggi, selektivitas dan aktivitas dalam reaksi kimia sehingga dapat dijadikan sebagai adsorb [9]. Zeolit memiliki porositas yang lebih besar bila dibandingkan dengan adsorben mesoporus silika.

Tujuan ulasan ini adalah melakukan studi kajian perbandingan hasil adsorpsi PAH (antracena, fenantrena dan fluorena) dengan adosorbenn karbon berpori, mesoporus silika dan zeolit, mengevaluasi parameter kinerja dan karakterisasi adsorpsi PAH menggunakan dengan adsorben karbon berpori, mesoporus silika dan zeolit.

\section{Metode Adsorpsi}

Pada umumnya, sistem adsorpsi terbagi atas dua macam, yaitu metode adsorpsi dengan sistem batch dan metode adsorpsi dengan sistem kontinyu. Pada sistem batch proses adsorpsi dilakukan pada sebuah wadah yang berisi adsorbat dengan adsorben. Kemudian dilakukan pengadukan pada kecepatan, waktu, dan suhu tertentu untuk menghasilkan kontak yang merata saat terjadi proses adsorpsi sedangkan adsorpsi sistem kontinyu dilakukan pada suatu sistem yang adsorben dan adsorbat selalu berkontak sehingga menghasilkan kontak yang relatif konstan. Metode yang banyak dilakukan dalam adsorpsi senyawa PAH ialah metode batch. Dalam literatur adsorpsi PAH yang dikaji terdapat beberapa parameter adsorpsi yaitu pengaruh $\mathrm{pH}$, temperatur, waktu kontak, konsentrasi analit, kemudian isoterm adsorpsi, studi kinetika dan termodinamika kimia. 
Purba, Br.W., dkk. Akta Kimia Indonesia 6(2), 2021, 174-186

Tabel 1. Metode Adsorpsi PAH berbagai jenis adsorben

\begin{tabular}{|c|c|c|c|}
\hline Adsorben & Metode adsorpsi & Jenis PAH & Sumber \\
\hline Karbon Aktif & $\begin{array}{l}\text { Metode Batch (analisis } \\
\text { PAH dengan Uv-Vis) }\end{array}$ & $\begin{array}{l}\text { PHE } \\
\text { ANT }\end{array}$ & {$[10,11]$} \\
\hline GAC (granula Active carbon) & $\begin{array}{l}\text { Metode Batch } \\
\text { (analisis PAH dengan } \\
\text { Uv/vis) }\end{array}$ & $\begin{array}{l}\text { NAP } \\
\text { FLU } \\
\text { ACE } \\
\text { ANT } \\
\text { PYR } \\
\text { FL }\end{array}$ & {$[12]$} \\
\hline PAC (powder active carbon) & $\begin{array}{l}\text { Metode Batch } \\
\text { (analisis PAH dengan } \\
\text { GC-MS) }\end{array}$ & $\begin{array}{l}\text { ANT } \\
\text { PYR } \\
\text { PHE }\end{array}$ & {$[13]$} \\
\hline Biochar & $\begin{array}{l}\text { Metode Batch (analisis } \\
\text { PAH dengan HPLC) }\end{array}$ & PHE & {$[14]$} \\
\hline Grafena & $\begin{array}{l}\text { Metode Batch (analisis } \\
\text { PAH dengan HPLC) }\end{array}$ & NAP & {$[15]$} \\
\hline $\begin{array}{l}\text { PMO (periodik mesoporus } \\
\text { organosilika ) }\end{array}$ & $\begin{array}{c}\text { Metode Batch } \\
\text { (analisis PAH dengan } \\
\text { GC-MS) }\end{array}$ & $\begin{array}{l}\text { ACE } \\
\text { FL } \\
\text { FLU } \\
\text { NAP } \\
\text { PYR }\end{array}$ & {$[16]$} \\
\hline $\begin{array}{l}\text { NH2-SBA-15 organic- } \\
\text { inorganic nanohybrid }\end{array}$ & $\begin{array}{l}\text { Metode Batch } \\
\text { (analisis PAH dengan } \\
\text { Uv/vis) }\end{array}$ & $\begin{array}{l}\text { NAP } \\
\text { PHE }\end{array}$ & [17] \\
\hline MCM-41 & $\begin{array}{l}\text { Metode Batch } \\
\text { (analisis PAH dengan } \\
\text { Uv/vis) }\end{array}$ & $\begin{array}{l}\text { NAP } \\
\text { PHE }\end{array}$ & {$[18,19]$} \\
\hline Klinoptilolit & $\begin{array}{l}\text { Metode Batch (analisis } \\
\text { PAH dengan Uv/vis) }\end{array}$ & $\begin{array}{l}\text { ANT } \\
\text { FL } \\
\text { FLU } \\
\text { PHE } \\
\text { PYR }\end{array}$ & {$[20]$} \\
\hline
\end{tabular}

$* P H E=$ Fenantrena,$A N T=$ Antrasena,$N A P=$ Naftalena,$F L U=$ Fluorantena,$F L=$ Fluorena,$P Y R=$ Pirena, dan ACE = Acenaftena . 
Pada Tabel 1 parameter adsorpsi yang dikaji dari beberapa adsorben seperti bahan karbon berpori (karbon aktif, biochar dan Grafena), zeolit dan mesoporus silika (PMO, MCM-41, dan $\mathrm{NH}_{2}$-SBA-15) masing-masing jurnal dievaluasi dengan analisis PAH yang berbedabeda seperti menggunakan Uv/vis (Ultraviolet/Visible), HPLC (High Performance Liquid Chromatography), dan GC-MS (Gas Chromatography-Mass Spectrometry).

Berikut merupakan tabel metode adsorpsi PAH dengan berbagai adsorben dan metode yang digunakan dalam analisis PAH.

\section{Parameter Adsorpsi}

\subsection{Pengaruh pH terhadap Adsorpsi}

Pada variasi $\mathrm{pH}$ untuk karbon aktif diperoleh bahwa adsorpsi maksimum pada $\mathrm{pH}$ 2,0 dengan proses adsorpsi yang diperoleh adalah $>90 \%$. Hal ini dikarenakan pada $\mathrm{pH}$ yang rendah terjadi penambahan muatan positif $\left(\mathrm{H}^{+}\right)$di permukaan karbon aktif sehingga interaksi antara karbon aktif dan PAH semakin tinggi. Namun pada $\mathrm{pH} 12,0$ terjadi proses adsorpsi yang minimum $<40 \%$, hal ini dikarenakan pada $\mathrm{pH}$ yang lebih tinggi, muatan positif pada permukaan karbon aktif akan berkurang dan muatan negatif (ion $\mathrm{OH}^{-}$) berinteraksi dengan molekul PAH untuk adsorpsi pada situs aktif, sehingga mengurangi efisiensi adsorpsi dari karbon aktif [10]. Berikut grafik yang diperoleh pada adsorpsi Fenantrena dengan karbon aktif.

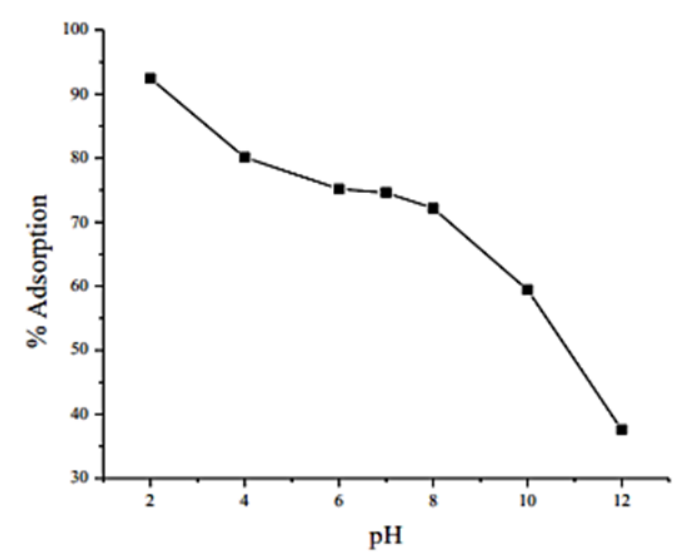

Gambar 1. Pengaruh $\mathrm{pH}$ terhadap persen adsorpsi Fenantrena.

Hasil yang berbeda diperoleh pada Biochar diperoleh bahwa tidak adanya variasi yang signifikan untuk adsorpsi PAH dengan Biochar dalam kisaran $\mathrm{pH}$ 2-11. Hal ini dikarenakan $\mathrm{PAH}$ merupakan senyawa organik non-ionik dan tidak terionisasi dalam larutan air. Sehingga pengaruh $\mathrm{pH}$ tidak akan mempengaruhi PAH juga pada Biochar. Pada $\mathrm{pH}$ rendah penambahan muatan positif $(\mathrm{H}+)$ hanya akan mengikat Biochar dengan gaya tarik elektrostatis [14]

Untuk Grafena, adsorpsi dengan PAH diperoleh bahwa pada $\mathrm{pH}$ yang tinggi interaksi yang dominan adalah interaksi hidrofobik [21]. Oleh karena itu semakin tinggi pH maka proses adsorpsi semakin meningkat. Dalam penelitian tersebut juga diperoleh bahwa adsorpsi Grafena memiliki kapasitas adsorpsi yang lebih rendah untuk PAH bila dibandingkan dengan Grafena Oksida. Jurnal yang berbedadalam hal proses adsorpsi PAH, 
peningkatan $\mathrm{pH}$ mengakibatkan terjadinya deprotanasi gugus fungsi $\mathrm{COOH}$ dan $\mathrm{OH}^{-}$dari Grafena Oksida. Gugus COO- bersifat donor elektron yang kuat sehingga interaksi antara Grafena dan PAH sangat kuat pada $\mathrm{pH}$ yang rendah. Grafena memiliki kapasitas adsorpsi yang lebih besar bila dibandingkan dengan Grafena Oksida, hal ini dikaitkan dengan interaksi $\Pi-\Pi$ pada Grafena Oksida memiliki kerapatan $\Pi$-elektron yang lebih rendah dan strukturnya mengandung lebih banyak kelompok fungsional Oksida [15]. Perbedaan persen adsorpsi Grafena dengan Grafena Oksida ditampilkan pada grafik berikut.

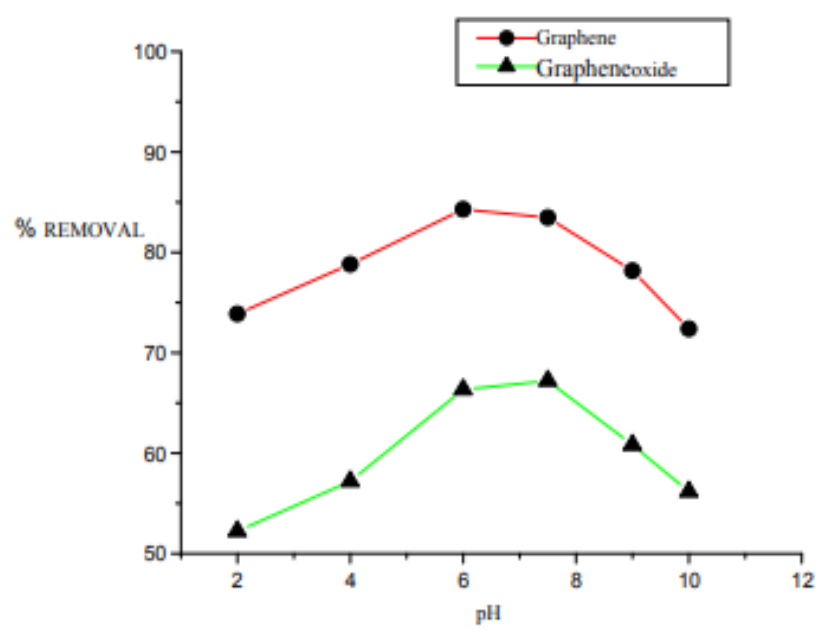

Gambar 2. Pengaruh $\mathrm{pH}$ terhadap persen adsorpsi Naftalena dengan Grafena dan Grafena Oksida [15]

Pada mesoporus silika, $\mathrm{NH}_{2}-\mathrm{SBA}-15$ kapasitas maksimum adsorpsi terjadi pada $\mathrm{pH}$ 2 dan mengalami penurunan kapasitas adsorpsi dengan meningkatnya $\mathrm{pH}$. Hal ini dikarenakan pada $\mathrm{pH}$ rendah terjadi pembentukan $\mathrm{NH}_{3}{ }^{+}$pada permukaan $\mathrm{NH}_{2}-$
SBA-15, sehingga terjadi peningkatan interaksi elektrostatis antara muatan permukaan adsorben dan PAH [17].

Hasil yang sama diperoleh pada MCM41, kapasitas maksimum adsorpsi terjadi pada $\mathrm{pH}$ 4. Pada $\mathrm{pH}$ yang rendah interaksi antara amina bermuatan positif dari adsorben MCM41 dalam media asam dan sistem elektron yang terdelokalisasi dari cincin aromatik PAH menghasilkan interaksi yang lebih tinggi antara molekul PAH dengan permukaan MCM-4 sebagai adsorben [19].

Untuk adsorpsi dengan Zeolit, hasil adsorpsi PAH tidak dipengaruhi oleh $\mathrm{pH}$. Hal ini dikarenakan sifat dari PAH maupun zeolit klinoptilolit yang digunakan. PAH memiliki struktur molekul yang stabil, tidak terionisasi dalam air dan stuktur yang dimiliki pada dasarnya tidak berubah seiring dengan perubahan $\mathrm{pH}$. Klinopilolit pada percobaan merupakan klinoptilolit yang dimodifikasi, adanya interaksi hidrofobik antara PAH dan suraktan pada permukaan klinoptilolit membuat $\mathrm{pH}$ tidak berdampak pada proses adsorpsi [20].

\subsection{Pengaruh Suhu terhadap Adsorpsi}

Pada karbon aktif adsorpsi meningkat saat suhu meningkat. Hal yang sama diperoleh pada mesoporus silika dengan meningkatnya suhu proses adsorpsi juga meingkat hal ini disebut dengan reaksi endoterm. Berikut adalah grafik pengaruh suhu terhadap persen adsorpsi pada karbon aktif [10]. 


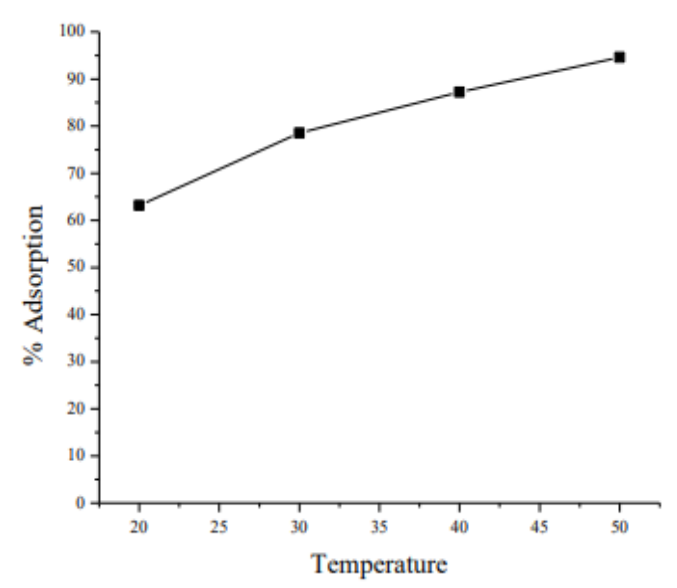

Gambar 3. Pengaruh suhu terhadap persen adsorpsi Fenantrena dengan karbon aktif [10].

Proses adsorpsi oleh Grafena pada grafik meningkat secara perlahan dengan meningkatnya suhu, kemudian mencapai kesetimbangan, namun pada suhu yang lebih tinggi situs aktif melemah sehingga proses adsorpsi menurun. Berikut adalah grafik persen adsorpsi PAH dengan suhu adsorpsi pada Grafena dan Grafena Oksida [15].

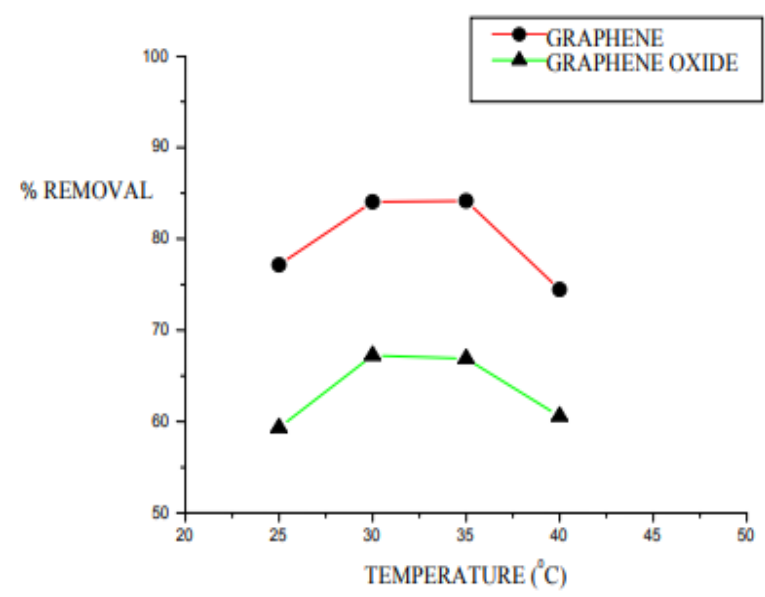

Gambar 4. Pengaruh suhu terhadap persen adsorpsi Naftalena dengan Grafena dan Grafena Oksida [15].

Pada zeolit klinoptilolit adsorpsi PAH berkurang dengan meningkatnya suhu dari 5 sampai $35^{\circ} \mathrm{C}$. Hal ini dikarenakan pada saat suhu dinaikkan kelarutan dari $\mathrm{PAH}$ juga semakin berkurang sehingga proses adsorpsi antara PAH dengan klinoptilolit lebih rendah bila dibandingkan dengan suhu rendah.

Untuk senyawa yang kelarutannya meningkat saat suhu meningkat diharapkan proses adsorpsi dilakukan pada suhu yang lebih tinggi. Namun proses adsorpsi tidak hanya bergantung pada kelarutan senyawa adsorbat, hal ini juga dipengaruhi dari adsorben yang digunakan

\subsection{Pengaruh waktu kontak terhadap adsorpsi}

Jumlah PAH yang teradsorpsi ke karbon aktif meningkat dengan meningkatnya waktu kontak, hal ini disebabkan oleh pengaruh migrasi yang lebih besar saat waktu yang lebih lama terhadap adsorpsi PAH. Kesetimbangan adsorpsi terjadi setelah proses adsorpsi selama 75 menit [10]. Grafik berikut menampilkan pengaruh lama nya waktu untuk proses adsorpsi terhadap persen adsorpsi Fenantrena.

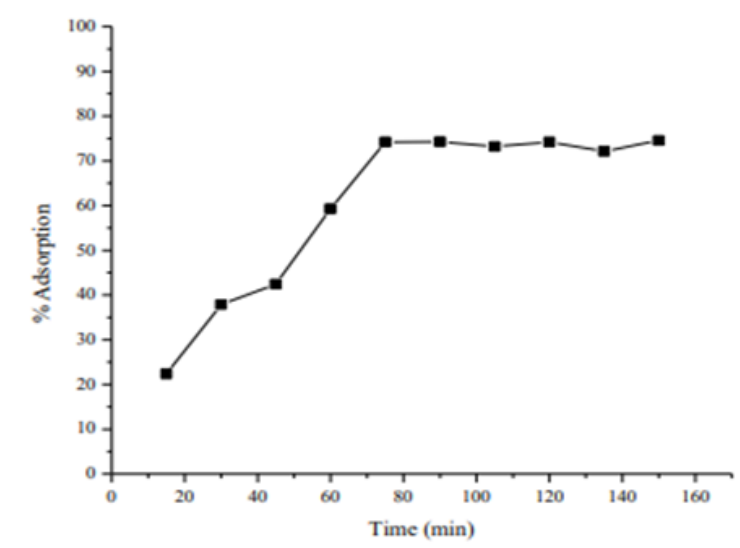

Gambar 5. Pengaruh waktu kontak terhadap persen adsorpsi Fenantrena dengan karbon aktif. 
Pada MCM-41 adsorpsi PAH terjadi sangat cepat pada 20 menit awal, lalu perlahan-lahan mencapai kesetimbangan dalam 60 menit dan tidak ada perubahan signifikan lebih lanjut dalam adsorpsi yang telah diamati sampai 2 jam [19]. Bila dibandingkan karbon aktif dengan MCM-41 waktu kesetimbangan adsorpsi pada karbon aktif lebih lama, hal ini dikarenakan porositas dan luas permukaan adsorben. Ukuran pori dan luas permukaan yang lebih besar pada mesoporus silika menyebabkan proses adsorpsi terjadi secara cepat, sehingga lebih cepat mencapai waktu kesetimbangan adsorpsi.

Pada adsropsi PAH dengan klinoptilolit adsorpsi meningkat saat waktu kontak meningkat, kesetimbangan adsorpsi diperoleh saat 24 jam hal ini dikarenakan konsentrasi awal PAH yang digunakan sangat sedikit sehingga membutuhkan waktu yang lama dalam proses adsorpsi. Waktu kontak juga dipengaruhi dari kelarutan dan sifat hidrofobik dari senyawa. [20].

\subsection{Pengaruh Konsentrasi PAH terhadap Adsorpsi}

Hal yang sama diperoleh pada setiap adsorben baik karbon berpori, mesoporus silika, maupun zeolit yang digunakan. Ketika konsentrasi awal meningkat maka waktu kesetimbangan akan tercapai lebih cepat dan kapasitas adsorpsi juga meningkat. Hal ini dikarenakan semakin banyak konsentrasi awal
PAH yang digunakan maka interaksi antara PAH dengan adsorben juga semakin mudah dan interaksi yang terjadi semakin meningkat sehingga lebih banyak PAH yang diadsorpsi dalam waktu yang lebih cepat. Molekul PAH yang lebih banyak berinteraksi dengan situs aktif adsorben menghasilkan kapasitas adsorpsi yang lebih tinggi. Dapat dilihat pada grafik pengaruh konsentrasi Fenantrena dengan kapasitas adsorpsi PAH sebagai berikut.

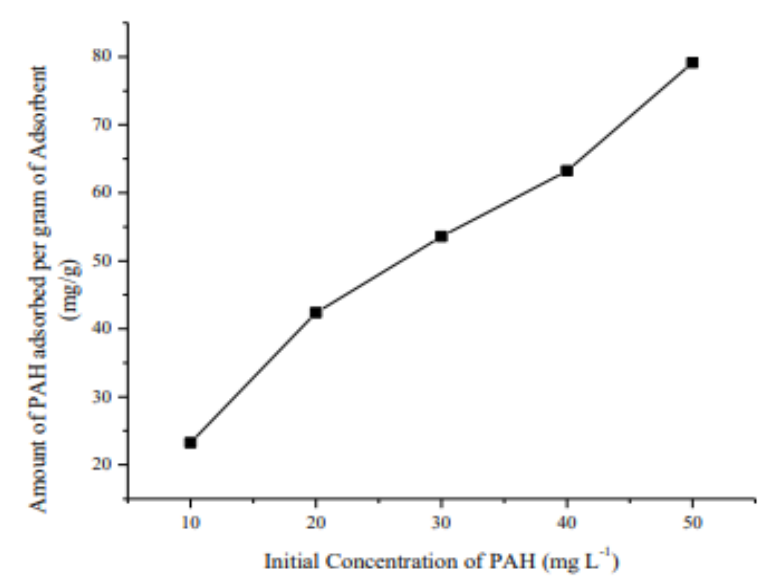

Gambar 6. Pengaruh konsentrasi awal Fenantrena terhadap kapasitas adsorpsi dengan karbon aktif.

\subsection{Isoterm Adsorpsi}

Isoterm adsorpsi dilakukan untuk menentukan karakteristik dari adsorpsi. Dari penelitian-penelitian yang dilakukan diperoleh bahwa setiap adsorben memiliki isoterm adsorpsi yang berbeda-beda. Hal ini dipengaruhi dari proses adsorpsi masingmasing adsorben. Isoterm Adsorpsi ditentukan dengan Persamaan Langmuir dan Freundlich. Isoterm Langmuir menggunakan 
3 pendekatan, yaitu adsorpsi terjadi di permukaan dan membentuk lapisan tunggal (monolayer), memiliki permukaan seragam dan situs adsorpsi yang sama serta hanya bias diisi oleh satu molekul adsorbat, serta tidak ada interaksi antara molekul pada berbagai situs. Isoterm Langmuir dapat dituliskan dalam bentuk persamaan sebagai berikut.

$$
\frac{1}{q_{e}}=\frac{1}{K_{L} q_{m}} \times \frac{1}{C_{e}} \times \frac{1}{q_{m}} \quad(\text { eq } 1)
$$

$\boldsymbol{C}_{\boldsymbol{e}}$ merupakan konsentrasi adsorbat pada saat kesetimbangan (mg.L $\left.\mathrm{L}^{-1}\right), \boldsymbol{q}_{\boldsymbol{e}}$ adalah kapasitas adsorpsi pada saat kesetimbangan (mg/g), $\mathrm{q}_{\mathrm{m}}$ dan qe pada monolayer (konstanta adsorpsi) dan $\mathrm{K}_{\mathrm{L}}$ adalah konstanta isoterm Langmuir( $1 / \mathrm{mg})$. Kurva linier antara $\frac{\boldsymbol{c}_{e}}{\boldsymbol{q}_{\boldsymbol{e}}}$ terhadap $\boldsymbol{C}_{\boldsymbol{e}}$ diplot berdasarkan adsorpsi hasil eksperimen kemudian ditentukan nilai $\boldsymbol{q}_{\boldsymbol{m}}$ dan dengan meninjau nilai slope dan intercept dari persamaan liniernya. Kemudian, dilakukan curve fitting dengan mensubstitusi nilai $\boldsymbol{q}_{\boldsymbol{m}}$ dan $\boldsymbol{K}_{\boldsymbol{L}}$ ke persamaan non-linier isoterm adsorpsi Langmuir yang ditunjukkan pada persamaan berikut.

$$
q_{e}=\frac{q_{m} K_{L} C_{e}}{1+K_{L} C_{e}} \quad(\text { eq } 2)
$$

Sedangkan isoterm Freundlich dapat digunakan dalam proses adsorpsi di permukaan yang heterogen dan membentuk monolayer [22]. Lalu bentuk linear isoterm Freundlich dapat dituliskan dalam persamaan berikut.

$$
\log q_{e}=\log K_{F}+\frac{1}{n} \log C_{e} \quad(\text { eq } 3)
$$

Dengan $\boldsymbol{q}_{\boldsymbol{e}}$ adalah kapasitas adsorpsi pada saat kesetimbangan $(\mathrm{mg} / \mathrm{g}) ; \boldsymbol{C}_{\boldsymbol{e}}$ adalah konsentrasi adsorbat pada saat kesetimbangan (mg. $\left.\mathrm{L}^{-1}\right) ; \quad \boldsymbol{K}_{\boldsymbol{F}}$ adalah konstanta isoterm Freundlich dan $\boldsymbol{n}$ adalah intensitas adsorpsi. Nilai $\boldsymbol{K}_{\boldsymbol{F}}$ dan $\boldsymbol{n}$ dapat ditentukan dari kurva linear antara $\log \boldsymbol{q}_{\boldsymbol{e}}$ terhadap $\boldsymbol{l o g} \boldsymbol{C}_{\boldsymbol{e}}$ dengan $\log \boldsymbol{K}_{\boldsymbol{F}}$ sebagai perpotongan (intercept) dan $\frac{\mathbf{1}}{\boldsymbol{n}}$ sebagai kemiringan (slope) pada persamaan linearnya. Kemudian, dilakukan curve fitting dengan mensubstitusi nilai $\boldsymbol{K}_{\boldsymbol{F}}$ dan $\boldsymbol{n}$ ke persamaan non-linier isoterm adsorpsi Freundlich yang ditunjukkan pada persamaan berikut [23].

$$
q_{e}=K_{F} C_{e^{\frac{1}{n}}}^{(\text {eq } 4) . ~}
$$

Untuk bahan karbon berpori terdapat adsorpsi senyawa PAH dengan Karbon aktif dan Grafena mengikuti model Langmuir, Biochar mengikuti model Sips yang merupaka gabungan dari model Freundlich dan Langmuir. Mekanisme adsorpsi PAH pada Biochar terjadi melalui interaksi-п dan interaksi hidrofobik yang kemudian senyawa PAH yang teradsorpsi akan masuk ke dalam pori-pori biochar melalui proses pengisian pori. Untuk bahan silika mesopori, Adsorpsi PAH dengan $\mathrm{NH}_{2}-\mathrm{SBA}-15$, dan MCM-41 mengikuti model Langmuir. 


\subsection{Kinetika Adsorpsi}

Kinetika adsorpsi dilakukan untuk menentukan difusi adsorbat ke dalam pori adsorben. Berdasarkan jurnal adsorpsi senyawa PAH dengan material karbon berpori, mesoporus silika, dan zeolit memiliki kinetika adsorpsi orde dua semu yang berarti bahwa adsorpsi PAH mengikuti proses chemisorption. Proses adsorpsi secara kimia (chemisorption) adalah proses adsorpsi yang melibatkan terjadinya reaksi kimia di permukaan adsorben, sehingga terjadi pembentukan ikatan antara adsorben dan adorbat. Kinetika pseudo orde dua diterapkan dengan persamaan:

$$
\frac{t}{q_{t}}=\frac{1}{K_{2} q_{e}^{2}}+\frac{t}{q_{e}} \quad(\text { eq } 5)
$$

dengan $\mathrm{K}_{2}$ adalah laju konstan pseudo orde dua $(\mathrm{mg} / \mathrm{g} / \mathrm{min})$.

Menurut model pseudo orde dua, laju reaksi sebanding dengan jumlah situs aktif pada permukaan adsrben dan permbatas laju reaksi adalah adsorpsi kimia antara adsorben dan adsorbat.

\subsection{Termodinamika Adsorpsi}

Termodinamika adsorpsi dilakukan untuk menentukan sifat mekanisme adsorpsi. Dengan parameter, perubahan entalpi $(\Delta H)$, perubahan energy Gibbs $(\Delta \mathrm{G})$, dan perubahan entropi $(\Delta S)$. Termodinamika adsorpsi berbeda beda. Hal ini dipengaruhi dari adsorben yang digunakan. Dengan persamaan-persamaan yang digunakan adalah sebagai berikut.

$$
\begin{aligned}
& \Delta \mathrm{G}^{\circ}=-\mathrm{RT} \ln \mathrm{K}_{\mathrm{c}} \\
& \log \mathrm{K}_{\mathrm{c}}=\frac{\Delta \mathrm{S}^{\circ}}{2,303 R}-\frac{\Delta \mathrm{H}^{\circ}}{2,303 R T} \\
& \Delta \mathrm{G}^{\circ}=\Delta \mathrm{H}^{\circ}-\mathrm{T} \Delta \mathrm{S}^{\circ} \\
& \mathrm{K}_{\mathrm{c}}=\frac{q_{e}}{C e}
\end{aligned}
$$

Dengan $\mathrm{C}_{\mathrm{e}}$ adalah jumlah $\mathrm{PAH}$ yang teradsorpsi ke dalam ZSM-5 dalam kondisi kesetimbangan (mg/L); R = 8,314 J/mol-K; $\mathrm{K}_{\mathrm{c}}$ adalah konstanta kesetimbangan; $\mathrm{T}$ adalah suhu $(\mathrm{K}) . \Delta \mathrm{H}^{\circ}$ dan $\Delta \mathrm{S}^{\circ}$ diperoleh dari kemingiran garis Antara $\log \mathrm{K}_{\mathrm{c}}$ dan 1/T [23].

Bila suatu adsorpsi terjadi dengan nilai $\Delta \mathrm{G}^{\circ}$ negatif dan nilai $\Delta \mathrm{H}^{\circ}$ positif secara jelas menunjukkan ke arah spontanitas dan sifat endotermik. Ketika nilai $\Delta \mathrm{H}^{\circ}$ positif maka nilai dari kapasitas adsorpsi akan meningkat seiring meningkatnya suhu dalam proses adsorpsi.

Dalam jurnal yang dikaji, Karbon aktif mengadsorpsi senyawa Antrasena secara spontan, endotermik $\left(\Delta \mathrm{H}^{\circ}\right.$ positif), dan memiliki nilai $\Delta S^{\circ}$ positif. Hal ini menunjukkan semakin tinggi suhu maka adsorpsi semakin disukai dan menghasilkan nilai kapasitas adsorpsi yang semakin meningkat [10].

$\mathrm{NH}_{2}$-SBA-15 mengadsorpsi senyawa $\mathrm{PAH}$ secara spontan $\left(\Delta \mathrm{G}^{\circ}\right.$ negatif $)$, endotermik $\left(\Delta \mathrm{H}^{\circ}\right.$ positif $)$, dan memiliki nilai 
$\Delta \mathrm{S}^{\circ}$ positif. Adsorpsi $\mathrm{PAH}$ dengan $\mathrm{NH}_{2}-\mathrm{SBA}-$

15 semakin spontan ketika suhu semakin meningkat. Berbeda dengan MCM-41 adsorpsi terjadi secara spontan $\left(\Delta \mathrm{G}^{\circ}\right.$ negatif $)$, eksotermik ( $\Delta \mathrm{H}^{\circ}$ negatif), dan memiliki nilai $\Delta S^{\circ}$ negatif. Hal ini menunjukkan bahwa adsorpsi dengan MCM-41 lebih disukai pada suhu rendah

\section{Kesimpulan}

Dari studi literatur diperoleh rentang parameter $\mathrm{pH}$ bahan karbon berpori 2-12; silika 2-10; zeolit 3-11, waktu kontak bahan karbon berpori 20 menit -24 jam; silika 5 menit-24 jam: zeolit 20 menit-48 jam, Suhu bahan karbon berpori $20-50^{\circ} \mathrm{C}$; silika 20 $45^{\circ} \mathrm{C}$; zeolit $5-35^{\circ} \mathrm{C}$, konsentrasi PAH bahan karbon berpori 10-50 mg/L; silika 2-60 mg/L; zeolit $50-100 \mu \mathrm{g} / \mathrm{L}$.

Setiap adsorben memiliki kelebihan dan kekurangan dalam mengadsoprsi PAH. Karbon aktif memiliki porositas yang tinggi namun sifatnya sangat bergantung pada bahan prekursor, suhu dan kondisi aktivasi. Biochar merupakan karbon berpori yang diolah dari bahan limbah sehingga penggunaannya dengan biaya yang murah. Grafena memiliki luas permukaan yang lebih tinggi dari karbon aktif dan memiliki interaksi ikatan hidrogen dan ikatan $\pi$ - $\pi$ PAH dengan adsorben lebih besar. Mesoporus silika lebih unggul dibandingkan karbon berpori karena porositas dan stabilitas yang tinggi serta afinitas kuat antara PAH dengan adsorben lain.

\section{Daftar Pustaka}

[1] A. O. Adeniji, O. O. Okoh, and A. I. Okoh, "Analytical Methods for Polycyclic Aromatic Hydrocarbons and their Global Trend of Distribution in Water and Sediment: A Review," in Recent Insights in Petroleum Science and Engineering, 2018, pp. 394-396.

[2] A. J. Forsgren, Wastewater treatment: Occurrence and fate of polycyclic aromatic hydrocarbons (PAHs). New York: CRC Press, 2015.

[3] Q. Wang et al., "Chemosphere Evaluation of fatty acid derivatives in the remediation of aged $\mathrm{PAH}$ contaminated soil and microbial community and degradation gene response," Chemosphere, vol. 248, p. 125983, 2020, doi: 10.1016/j.chemosphere.2020.125983.

[4] M. A. Nkansah, A. A. Christy, and T. Barth, "The use of anthracene as a model compound in a comparative study of hydrous pyrolysis methods for industrial waste remediation," Chemosphere, vol. 84, no. 4, pp. 403408, 2011, doi: 10.1016/j.chemosphere.2011.03.061.

[5] M. El Khames Saad, R. Khiari, E. Elaloui, and Y. Moussaoui, "Adsorption of anthracene using activated carbon and Posidonia oceanica," Arab. J. Chem., vol. 7, no. 1, pp. 109-113, 2014, doi: 10.1016/j.arabjc.2013.11.002.

[6] A. Mojiri, J. L. Zhou, A. Ohashi, N. 
Ozaki, and T. Kindaichi, "Comprehensive review of polycyclic aromatic hydrocarbons in water sources, their effects and treatments," Sci. Total Environ., vol. 696, p. 133971, 2019, doi: 10.1016/j.scitotenv.2019.133971.

[7] G. Gbeddy, A. Goonetilleke, G. A. Ayoko, and P. Egodawatta, "Transformation and degradation of polycyclic aromatic hydrocarbons (PAHs) in urban road surfaces: Influential factors, implications and recommendations," Environ. Pollut., p. 113510, 2019, doi: 10.1016/j.envpol.2019.113510.

[8] C. F. Chang, C. Y. Chang, K. H. Chen, W. T. Tsai, J. L. Shie, and Y. H. Chen, "Adsorption of naphthalene on zeolite from aqueous solution," J. Colloid Interface Sci., vol. 277, no. 1, pp. 2934, 2004, doi: 10.1016/j.jcis.2004.04.022.

[9] H. Zhao, J. Ma, Q. Zhang, Z. Liu, and R. Li, "Adsorption and Diffusion of n Heptane and Toluene over Mesoporous ZSM-5 Zeolites," Ind. Eng. Chem. Res., vol. 53, no. 35, pp. 13810-13819, 2014, doi: 10.1021/ie502496v.

[10] H. Gupta, "Removal of Phenanthrene from Water Using Activated Carbon Developed from Orange Rind," Int. J. Sci. Res. Environ. Sci., vol. 3, no. 7, pp. 248-255, 2015, doi: 10.12983/ijsres2015-p0248-0255.

[11] H. Gupta, "Anthracene removal from water onto activated carbon derived from vehicular tyre," Sep. Sci. Technol., vol. 53, no. 4, pp. 613-625, 2018 , doi:

DOI: http://dx.doi.org/10.12962/j25493736.v6i2.9725
10.1080/01496395.2017.1405038.

[12] D. Eeshwarasinghe, P. Loganathan, M. Kalaruban, D. P. Sounthararajah, J. Kandasamy, and S. Vigneswaran, "Removing polycyclic aromatic hydrocarbons from water using granular activated carbon: kinetic and equilibrium adsorption studies," Environ. Sci. Pollut. Res., vol. 25, no. 14, pp. 13511-13524, 2018, doi: 10.1007/s11356-018-1518-0.

[13] A. Rasheed, F. Farooq, U. Rafique, S. Nasreen, and M. Aqeel Ashraf, "Analysis of sorption efficiency of activated carbon for removal of anthracene and pyrene for wastewater treatment," Desalin. Water Treat., vol. 57, no. 1, pp. 145-150, 2016, doi 10.1080/19443994.2015.1015304.

[14] W. Guo, S. Wang, Y. Wang, S. Lu, and Y. Gao, "Sorptive removal of phenanthrene from aqueous solutions using magnetic and non-magnetic rice husk-derived biochars," R. Soc. Open Sci., vol. 5, no. 5, 2018, doi: 10.1098/rsos.172382.

[15] P. Das, S. Goswami, and S. Maiti, "Removal of naphthalene present in synthetic waste water using novel Graphene /Graphene Oxide nano sheet synthesized from rice straw: comparative analysis, isotherm and kinetics," Front. Nanosci. Nanotechnol., vol. 2, no. 1, pp. 38-42, 2016, doi: 10.15761/fnn.1000107.

[16] C. B. Vidal et al., "Adsorption of polycyclic aromatic hydrocarbons from aqueous solutions by modified periodic mesoporous organosilica," J. Colloid Interface Sci., vol. 357, no. 2, pp. 466- 
473,

2011 ,

10.1016/j.jcis.2011.02.013.

[17] A. Balati, A. Shahbazi, M. M. . Amini, and S. H. Hashemi, "Adsorption of polycyclic aromatic hydrocarbons from wastewater by using silica-based organic - inorganic nanohybrid material," J. Water Reuse Desalin., vol. 05, no. 1, pp. 50-63, 2015, doi: 10.2166/wrd.2014.013.

[18] Y. Hu, Y. He, X. Wang, and C. Wei, "hydrophobic MCM-41 molecular sieves," Appl. Surf. Sci., pp. 3-6, 2014, doi: 10.1016/j.apsusc.2014.05.173.

[19] T. M. Albayati and K. R. Kalash, "Polycyclic aromatic hydrocarbons adsorption from wastewater using different types of prepared mesoporous materials MCM-41in batch and fixed bed column," Process Saf. Environ. Prot., pp. 13-18, 2019, doi: 10.1016/j.psep.2019.11.007.

[20] M. Hedayati, "Removal Of Polycylic Aromatic Hydrocarbon From
Deionized Water \& Landfill Leachate By Using Modified Clinoptilolites," 2018.

[21] Y. Sun, S. Yang, G. Zhao, Q. Wang, and $\mathrm{X}$. Wang, "Adsorption of polycyclic aromatic hydrocarbons on graphene oxides and reduced graphene oxides," Chem. - An Asian J., vol. 8, no. 11, pp. 2755-2761, 2013, doi: 10.1002/asia.201300496.

[22] N. Ayawei, A. N. Ebelegi, and D. Wankasi, "Modelling and Interpretation of Adsorption Isotherms," J. Chem., vol. 2017, no. September, 2017, doi: 10.1155/2017/3039817.

[1] [23] A. Kumar et al., "One pot Green Synthesis of Nano magnesium oxide-carbon composite: Preparation, characterization and application towards anthracene adsorption," J. Clean. Prod., vol. 237, 2019, doi: 10.1016/j.jclepro.2019.117691. 